\title{
Techniques of the Smart Textile Utilization as Soilless Board in Vertical Cultivation
}

\author{
El-Sayed Sehsah1, El Sayed El Nashar² \\ ${ }^{1}$ Department of Agriculture Engineering, Faculty of Agriculture, Kaferelsheikh University, Egypt \\ ${ }^{2}$ Department of Home Economic, Faculty of Specific Education, Kaferelsheikh University, Egypt \\ Email: sehsah_2000@yahoo.de, smartex@kfs.edu.eg
}

How to cite this paper: Sehsah, E.-S. and El Nashar, E.S. (2022) Techniques of the Smart Textile Utilization as Soilless Board in Vertical Cultivation. Journal of Textile Science and Technology, 8, 58-67. https://doi.org/10.4236/jtst.2022.81006

Received: January 1, 2022

Accepted: February 21, 2022

Published: February 24, 2022

Copyright $\odot 2022$ by author(s) and Scientific Research Publishing Inc. This work is licensed under the Creative Commons Attribution-NonCommercial International License (CC BY-NC 4.0). http://creativecommons.org/licenses/by-nc/4.0/ (c) (i) $($ Open Access

\begin{abstract}
Vertical cultivation is the most important method in the future spatially in smart agriculture systems. The fourth different thickness soilless textile was used as the board to cultivate water-cress (Eruca Sativa). The vacuum pump model VRI V3 Dual Stage Vacuum Pump was constructed and used in the preliminary experimental test. It's run to measure the water content and water absorption percentage for soilless board under lab conditions. Different tests were evaluated for the absorption sample after elapsed time $0.08,0.17$, $0.25,5,24$ and 120 hours. Soilless board textile with thickness $32 \mathrm{~mm}, 26 \mathrm{~mm}$, $21 \mathrm{~mm}$ and $16 \mathrm{~mm}$ made from the following material: woven fabric of Cotton. The four mattresses of smart textile as soilless vertical cultivation, measuring $40 \mathrm{~cm}$ width $60 \mathrm{~cm}$ length were created; it has filler from soft sawdust, a mixture of red (beech) and white (Swedish) wood. The result of preliminary test illustrated that the soilless board may be able to keep the amount of water for more than $72.3 \%$ after 5 days from edit water to soilless board. The soilless smart with $32 \mathrm{~mm}$ thickness gave highly growths of water-cress compared with the other smart mattress.
\end{abstract}

\section{Keywords}

Soilless, Vertical Cultivation and Smart Textile

\section{Introduction}

The vertical cultivation soilless may be able to solve the problems of soil contamination. Vertical farming and Vertical cultivation are some of the many ideas being further developed by various re-research groups, corporations, and ordinary citizens. Because of the growing problems of urbanization, with the growing population, vertical farming has presented itself as a possibility to feed people, 
especially in large and densely populated cities, in an efficient and environmentally friendly manner. Interestingly, while agricultural textiles are often used in agriculture and textile fabrics can be purchased, only a few researchers have studied the possibilities of using woven fabrics as substrates for vertical wandering so far [1].

The main challenge facing the water sector in Egypt is to bridge the rapidly growing gap between the limited water resources and the increasing demand for water and to determine the water quality for agricultural, domestic and industrial pollution sources and how to adopt this water degradation A new source of water that can keep pace with water reuse standards at various stages [2].

Water needs in Egypt are constantly increasing due to population increase and improvement in lifestyle as well as government policy to reclaim more land and encourage industrialization. The water needs of the agricultural division represent the important component of the total water demand in Egypt [3]. Agriculture consumes more than $85 \%$ of Egypt's share of the Nile water annually. Municipal and industrial water requirements represent a smaller portion of the total water requirements in Egypt. Consequently, there may be a need to reallocate the available water resources to meet these future requirements. Saline water is a potential source of irrigation, as soil, crop, water, irrigation and drainage management techniques enhance and facilitate the use of saline water for crop irrigation with minimal adverse effects on soil productivity and the environment. In connection with irrigation, the use of water of marginal quality will require careful planning, more complex management practices and strict control procedures compared to the use of water of good quality [4] [5].

This saline water may cause salt build-up, sodium absorption and SAR increase (SAR) in irrigated soils, re-permeability and natural drainage properties. Cultivation of vegetable crops on compressed rice straw bales has been practiced in Egypt as an empirical scale by strawberry, pepper, tomato, cucumber and okra in the open field or under greenhouse using irrigation fresh water (IW) [6] [7] investigated the substitution of rice straw as a tool to avoid problems inherent in diseased natural soils for strawberry production.

In Dokki, Giza Greenhouse Experiment [8], the addition of rice straw to form $20 \%$ of the media for eggplant cultivation, and the use of free-living rhea-fixing bacteria to cover nitrogen deficiency in rice straw when used as a growing medium was tested. Bacteria increased crop yield while higher air temperature and relative humidity caused lower crop yield and net yield. The major idea of this article is of vertical farming is to grow vegetables or other plants vertically, typically inside tall buildings. One possibility is to have several cliff-like floors. With a view to being used for agriculture. Water is often carried from the highest levels down to the next levels until it reaches the lowest level and is pumped back to the highest level, ideally achieving a closed water recirculation system. On a large scale, entire skyscrapers can be used for vertical farming, including perhaps a restaurant or supermarket where vegetables are sold. On a smaller range, vege- 
tables are harvested from the paths between the shelves on which they grow [9]. Recently indicated that indoor vertical farming may support improved nutrition, reduced water consumption, and reduced risks associated with outdoor cultivation due to increased climate change and maximum weather conditions.

However, even in wealthier countries, the total area of agricultural land is often insufficient to cover the food needs of the population [10]. This is one of the reasons why vertical farming is so important in research and development. Vertical farming may provide a certain amount of independence, especially in highly urbanized areas [11]. Interestingly, vertical farming can economically compete with fresh foods grown in greenhouses, despite the high cost of artificial lighting [12]. From an artistic point of view, comparatively new technologies such as hydroponics, aeroponics and aquaponics facilitate efficient city farming [13]. Another technique based on the same idea of growing plants vertically to save space is shown by BIQ Algenhaus in Hamburg, Germany. The facade of this building is used as a bioreactor in which microalgae are grown. Through growth, microalgae absorb radiation on the facade, partially refundable converting it into biomass, while the remaining radiation is used to heat the building. Nutrients are supplied through wastewater from the building, again achieving the high recycling rate observed in common vertical farming techniques [14] [15] describe textile substrates for the microalgae Saccharine lentissimo, which were cultured on fabrics at different development stages.

Continuous physical force exerted on or against an object by something in contact with it. In a binder solution, the microalgae-forming marine algae were affixed to polyester rope and non-woven fabric. Facilitating the outgrowing of algae in this way in a seaweed farm at an early stage not only increased the amount of biomass produced, but also helped reduce the necessary size of spawning tanks [16]. They found polypropylene nets laid near the edge of mangroves in the bay in southern Brazil where they conducted their experiment that enabled farming using simple technology and led to a reliable growth rate of algae, provided that local residents with a secure income. Agro-textiles are found more suitable than dark-black plastic of polyethylene and sawdust for strawberries, which have a high content of ascorbic acid. However, conventional straw mulch resulted in the best fruit size and yield [17]. For early potato harvests, coverage made of agricultural fabric yielded larger potatoes than cover made of perforated plastic or no cover at all [18].

\section{Objectives}

Evaluation vertical soilless simulated greenhouse manufactured, and fabricated from local materials and utilization of the textile; as the soilless board in vertical cultivation under laboratory conditions.

\subsection{Materials and Methods}

The laboratory small vertical soilless simulated greenhouse was and fabricated 
from local materials at the farm machinery laboratory, agricultural engineering department, faculty of agriculture, Kaferelsheikh University. It consists of the frame that made from aluminum as shown in Figure 1. It is supported on the four edges by the $U$ cross-section with $900 \mathrm{~mm}$ height from the ground, $600 \mathrm{~mm}$ width and $450 \mathrm{~mm}$ depth. The fourth different thickness soilless board textile mattresses were used as the board to cultivate water-cress or Ervum ervilia. The four mat-tresses were put on four shelves in the vertical structured frame and simulated in small greenhouse by using the plastic Polythene sheet 40 micron as the cover of the simulated small greenhouse. Two different light sources were used $40 \mathrm{~W}$ bulb lamp and $9 \mathrm{~W}$ led lamp.

\subsection{Soilless Board Textile $32 \mathrm{~mm}, 26 \mathrm{~mm}, 21 \mathrm{~mm}$ and $16 \mathrm{~mm}$}

The soilless board is made from the following material: Yarn and fabric specification of Damour Cotton Fabric as shown in Table 1.

Cotton Fabric-Damour (With Raw Bafttah) according ASTM D5867-12(2020) [19] 8 Standard Test Methods for Measurement of Physical Properties of Raw Cotton by Cotton Classification Instruments, and Egyptian General Authority for Standardization and Quality, Number (278/2013) [20]. These standard specifications are concerned with the local production of damour fabrics (Raw Baftteh) made from Egyptian cotton spinning, used in the furniture industry, etc.

\subsubsection{Soilless Board Filler}

The Filler of soilless board was from soft sawdust of a mixture of $50 \%$ volume red (beech) and 50\% volume white (Swedish) wood. The four mattresses of smart textile as: soilless vertical cultivation, measuring $40 \mathrm{~cm}$ width $60 \mathrm{~cm}$ length
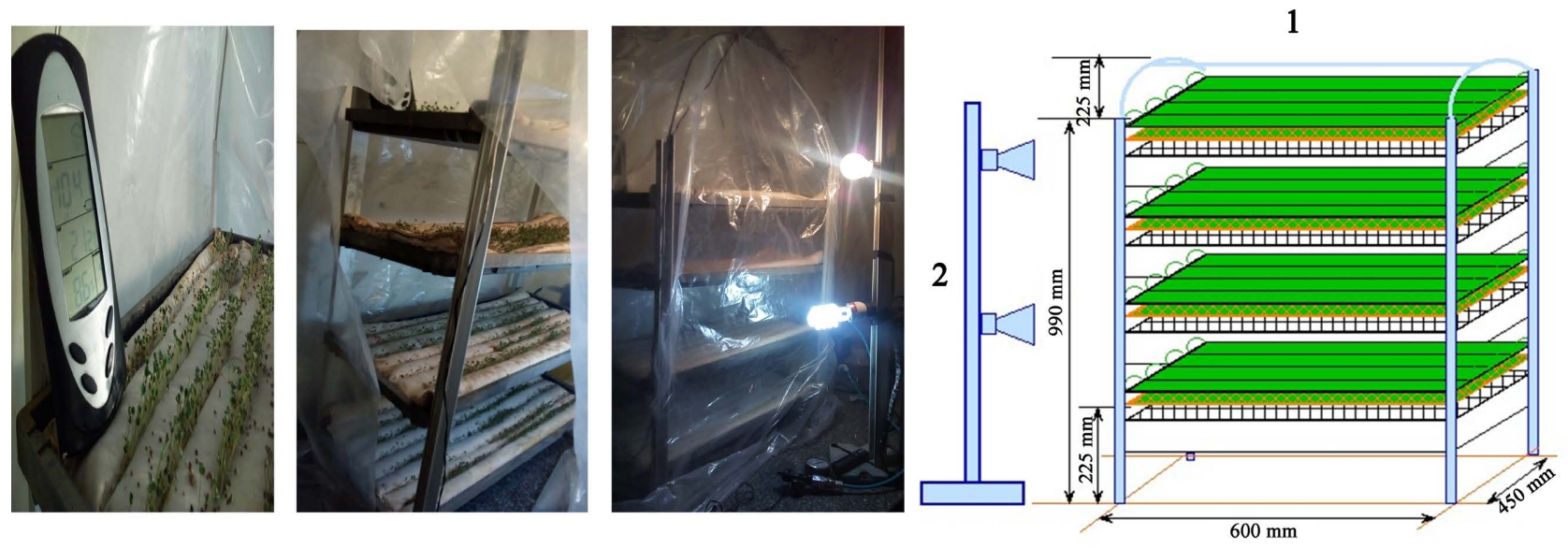

Figure 1. Present the laboratory vertical cultivation simulated small greenhouse.

Table 1. Fabrics specification of soilless board textile mattresses $32 \mathrm{~mm}, 26 \mathrm{~mm}, 22 \mathrm{~mm}$ and $16 \mathrm{~mm}$.

\begin{tabular}{ccccccc}
\hline & Material & density & Count & Type & Spinning system & twist factor \\
\hline Yarn & Cotton $100 \%$ & $20 / \mathrm{cm}$ & $29.525 \mathrm{Tex}$ & Single yarn strength (cN/tex) & Ring spinning, Carded yarn & 3.6 \\
Weft & Cotton $100 \%$ & $20 / \mathrm{cm}$ & $29.525 \mathrm{Tex}$ & Single yarn strength (cN/tex) & Ring spinning, Carded yarn & 3.6 \\
\hline
\end{tabular}


were created, it has 5 sides of equal width, Filler from soft sawdust, a mixture of red (beech) and white (Swedish) wood.

- The thickness of the first soilless board is $32 \mathrm{~mm}$ with weight $4200 \mathrm{gm}$.

- The thickness of the second soilless board is $26 \mathrm{~mm}$ with weight $2900 \mathrm{gm}$.

- The thickness of the third soilless board is $21 \mathrm{~mm}$ with weight $2400 \mathrm{gm}$.

- The thickness of the fourth soilless board is $16 \mathrm{~mm}$ with weight $1600 \mathrm{gm}$.

The first soilless boards are put on the plastic frame in top position and follow the second, third fourth soilless board in bottom position.

The environmental instrument model Standard ST2232 was used to measure the relative humidity, temperature and light density. Also, the data logger TRONIC was fixed to measure the temperature inside and outside of the simulated small greenhouse.

\subsubsection{Procedure}

The experimental was carried out under laboratory conditions as the simulator of the soilless vertical cultivation using the smart textile in laboratory of agriculture engineering department, faculty of agriculture, Kafrelsheikh University. The preliminary experimental test to measure the water content and water absorption percentage and rate in the soilless board was investigated and evaluated under lab conditions. The vacuum pump model VRI V3 Dual Stage Vacuum Pump was constructed as shown in Figure 2. The pump operated under different elapsed time and operating pressure $5 \mathrm{MPa}(0.5)$ bar to obtain the water volume absorption percentage and absorption rate in the soilless board. The manometer and mechanical valve, tubes, water collector tank and spiral suction tube were constructed in absorption unit test.

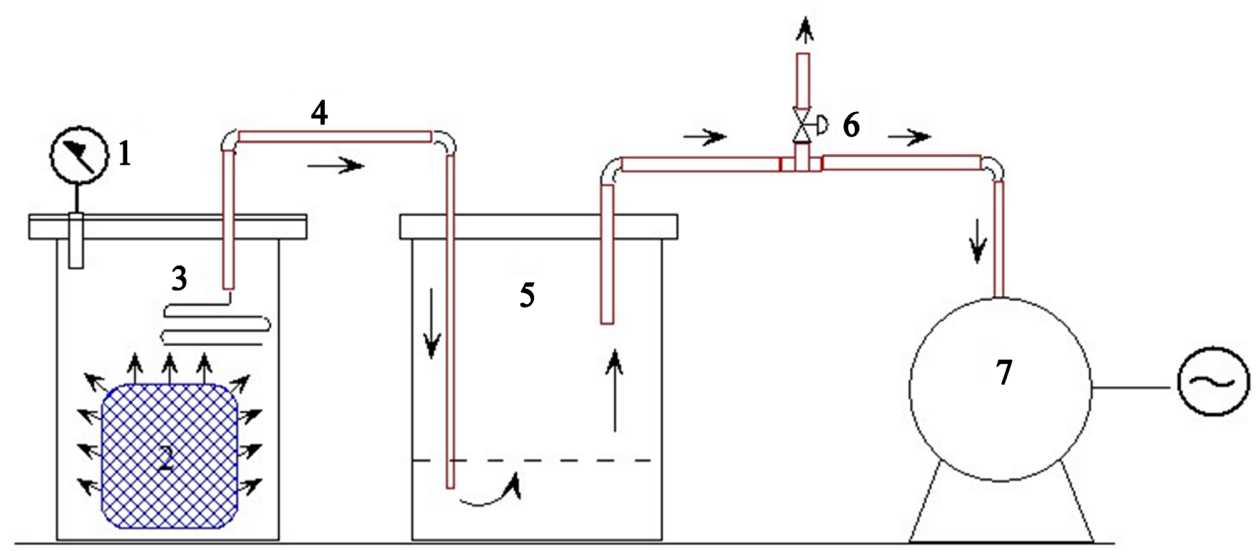

1 Pressure manometer

2 Textile sample

3 spiral suction tube

4 PVC tube

5 Water collector tank

6 valve

7 Vacuun air puunp

Figure 2. Test diagram to measure the water content and water absorption percentage in the soilless board. 
Water absorption is expressed as increase in weight percent.

Percent Water Absorption $=100 \times[(\mathrm{A}-\mathrm{B}) / \mathrm{B}], \%$

A Wet weight, $g$

B Dry weight, $\mathrm{g}$

Amount of water percent $=100 \times[1-(\mathrm{A}-\mathrm{B}) / \mathrm{B}], \%$

Water absorption is the amount of water taken up by flour to achieve the desired consistency and create a quality end-product. It is the optimal amount of water you can add to dough before it becomes too sticky to process. The textile mattress sample weights $86.5 \mathrm{~g}$ was put in aluminum container $750 \mathrm{ml}$ capacity and edited the water until the sample absorbed the amount of water. The sample was weighted before and after editing the amount of water into container. The vacuum pump operated and adjusted the suction pressure at $5 \mathrm{MPa}$ at elapsed operating time $30 \mathrm{~s}$. Different tests were evaluated for the absorption sample after elapsed time $0.08,0.17,0.25,5,24$ and 120 hours. The amount of water in collector tank is weighted to estimate the water absorption in the sample at different elapsed time.

\section{Laboratory Experimental}

To cultivate the water-cress or Ervum ervilia (Eruca Sativa) in vertical cultivation unit, soilless board was irrigated with $3000 \mathrm{ml}$ water and the seeds of Eruca Sativa were distributed in rows on the soilless boards. The spray irrigation was applied to edit the amount of water. After cultivation of the Eruca Sativa, the morphology of the plant, length, number of leaves was recorded for 2 weeks and after 24 hours elapsed time from the planting.

\section{Results and Discussion}

The result of preliminary water absorption test illustrated that the textile soil less board may be able to keep and absorb the amount of water for more than $72.3 \%$ after 5 days or 120 hours from irrigated or edited water to soilless board mattress as shown in Figure 3 and Table 2. The maximum value of percentage of water amount or absorption percent was $86.7 \%$ after 5 min from edit water or irrigated. There are non-significant after $15 \mathrm{~min}$ from irrigated or edit water amount to soilless board. The value of water amount or absorption percent was $75.63 \%$ after 24 hours. As well as, the water amount percent educed by increasing of elapsed time as shown in Table 2.

\subsection{Result of the Experimental}

The result focused on the ability to cultivate in soilless board as vertical cultivation method and using the smart textile material in the soilless. The weather condition is indicated in Figure 4 for inside and outside of vertical soilless cultivation unit. The average values of light density were recorded the values 260, 136 and 116 Lux at three level height every $30 \mathrm{~cm}$ from the top to the bottom in vertical soilless cultivation unit. The maximum value for relative humidity recorded 


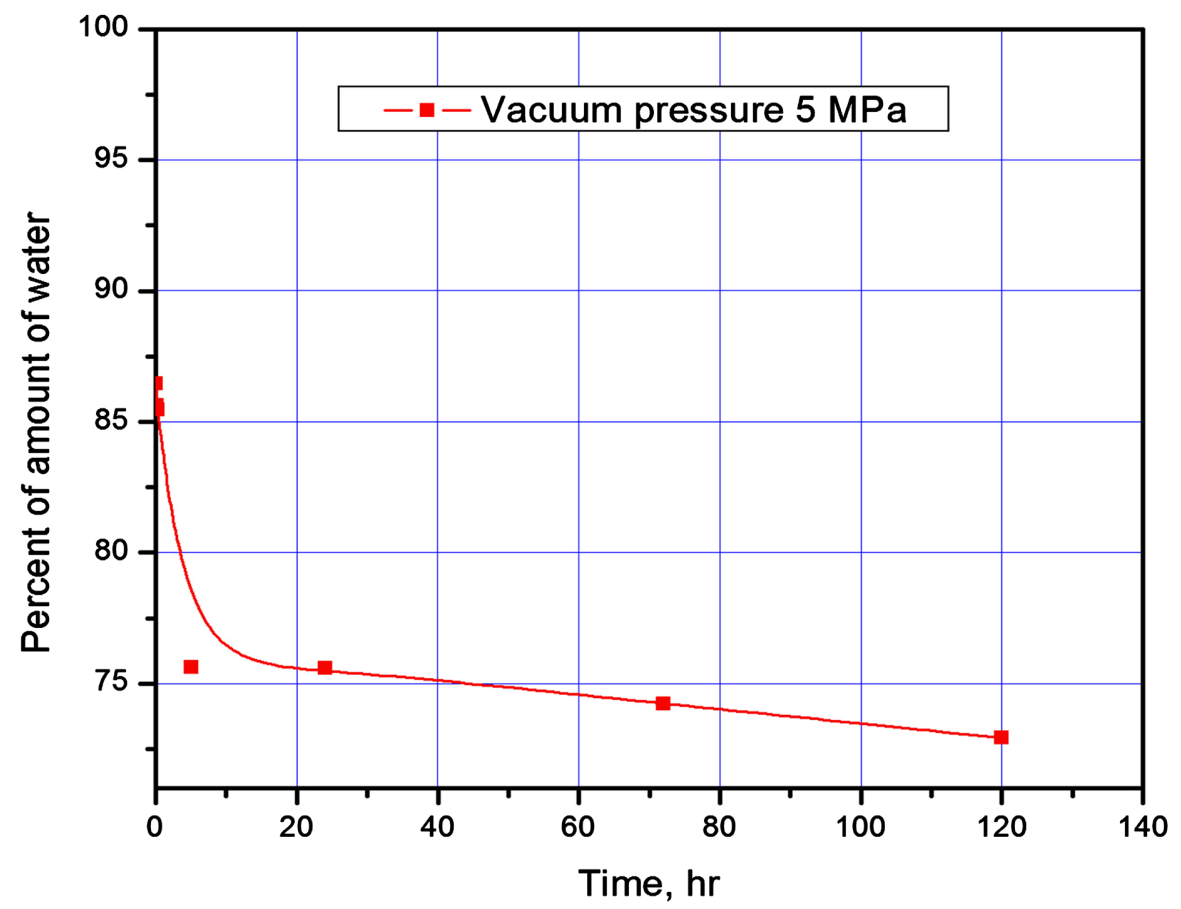

Figure 3. The relation of water amount percent and elapsed time for soilless board mattress at negative pressure $5 \mathrm{MPa}$.

Table 2. The percent of water amount or absorption of water in soilless board mattress at negative pressure $5 \mathrm{MPa}$.

\begin{tabular}{|c|c|c|c|c|c|c|c|}
\hline sample weight, g & $\begin{array}{c}\text { Edit water, } \\
\text { g }\end{array}$ & $\begin{array}{l}\text { Time, } \\
\min \end{array}$ & $\begin{array}{c}\text { Vacuum pressure, } \\
\mathrm{MPa}\end{array}$ & $\begin{array}{c}\text { total weight, } \\
\mathrm{g}\end{array}$ & $\begin{array}{c}\text { net weight, } \\
\text { g }\end{array}$ & $\begin{array}{c}\text { Removed water, } \\
\%\end{array}$ & $\begin{array}{c}\text { Absorption, } \\
\%\end{array}$ \\
\hline 107.9 & 750 & 5 & 5 & 796.1 & 688.2 & 13.55 & 86.45 \\
\hline 107.9 & 750 & 10 & 5 & 751.1 & 643.2 & 14.37 & 85.63 \\
\hline 107.9 & 750 & 15 & 5 & 742.4 & 634.5 & 14.53 & 85.47 \\
\hline 107.9 & 750 & 300 & 5 & 442.8 & 334.9 & 24.37 & 75.63 \\
\hline 107.9 & 750 & 1440 & 5 & 442.2 & 334.3 & 24.40 & 75.60 \\
\hline 107.9 & 750 & 4320 & 5 & 418.7 & 310.8 & 25.77 & 74.23 \\
\hline 107.9 & 750 & 7200 & 5 & 398.6 & 290.7 & 27.07 & 72.93 \\
\hline
\end{tabular}

$90.7 \%$ inside and $73 \%$ outside of small greenhouse or vertical cultivation unit. As well as, the maximum temperature was $25.7^{\circ} \mathrm{C}$ and $24.2^{\circ} \mathrm{C}$ for inside and outside of vertical cultivation unit respectively.

\subsection{Morphological Result}

The growths of water-cress (Eruca Sativa) in vertical cultivation unit were recorded every 24 hours. It was noticed that the soilless smart mattress with $32 \mathrm{~mm}$ thickness gave highly growths of water-cress (Eruca Sativa) compared with the other smart mattress as shown in Figure 5. The height, area of leaves and number of leaves were measured and listed in Table 2. The smart soilless mattress with $32 \mathrm{~mm}$ thickness gave the highly planting area compared with the $26 \mathrm{~mm}$, 

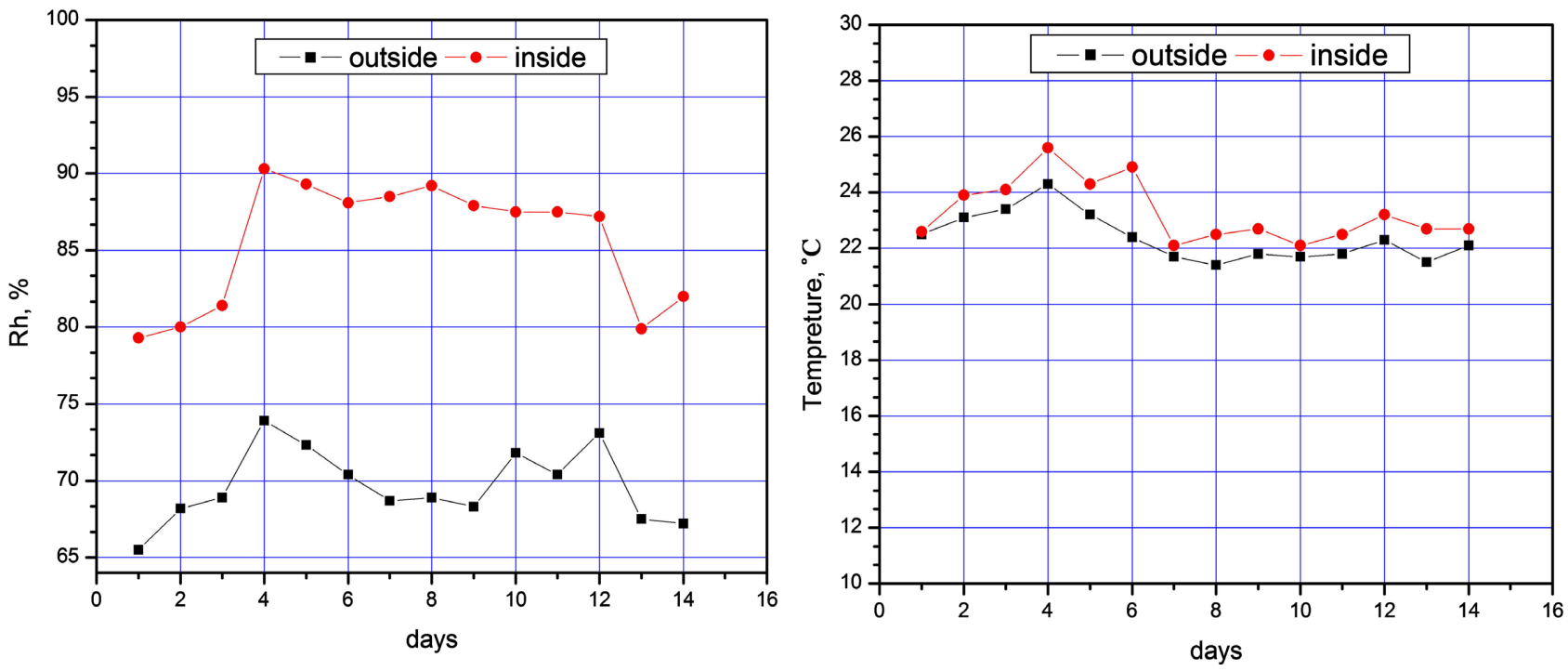

Figure 4. The measuring data of weather inside and outside for vertical soilless cultivation small greenhouse unit under Lab.

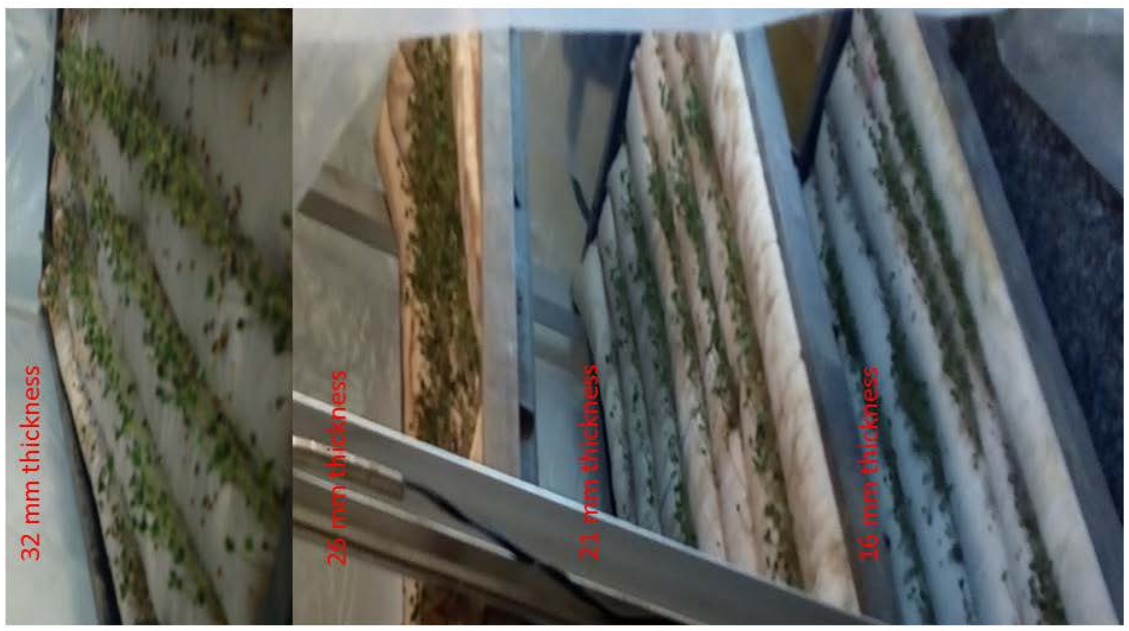

Figure 5. The growths of water-cress (Eruca Sativa) in vertical cultivation unit.

Table 3. Display the average values of morphology measuring of the growth water-cress (Eruca Sativa) plant in vertical cultivation unit.

\begin{tabular}{|c|c|c|c|c|}
\hline \multirow{2}{*}{$\begin{array}{c}\text { Thickness of } \\
\text { soilless board, } \mathrm{mm}\end{array}$} & \multirow{2}{*}{$\begin{array}{c}\text { Total area } \\
\text { of planting, } \mathrm{cm}^{2}\end{array}$} & \multicolumn{3}{|c|}{ Height, mm } \\
\hline & & After 3 days & After 7 days & After, 14 days \\
\hline 32 & 620 & 42.5 & 49.7 & 98.9 \\
\hline 26 & 595 & 34.2 & 40.9 & 67.7 \\
\hline 21 & 406 & 31.3 & 36.0 & 66.2 \\
\hline 16 & 367 & 30.5 & 34.1 & 61.8 \\
\hline
\end{tabular}

$21 \mathrm{~mm}$ and $16 \mathrm{~mm}$ thickness. There are plantations of all rows in $32 \mathrm{~mm}$ mattress without despaired of planting of (Eruca Sativa) seed compared with low thickness of soilless smart textile. This result may be due to the water absorption or water amount in $32 \mathrm{~mm}$ mattress. The height of the water-cress was $42.5 \mathrm{~mm}$ 
height after 72 hours from the planting of the seeds in $32 \mathrm{~mm}$ thickness of soilless smart textile. The increasing of thickness may be increasing the growth of the plant and good condition for vertical cultivation unit as shown in Table 3.

\section{Conclusion}

To summarize, Techniques of the Smart Textile Utilization as Soilless Board in Vertical Cultivation can be used for a broad variety of agricultural applications, in particular protecting plants from excessively cold or warm weather, insects, bacterial contaminations, etc. The soilless vertical cultivation with $32 \mathrm{~mm}$ thickness produced a good condition of plant growth under current research conditions.

\section{Conflicts of Interest}

The authors declare no conflicts of interest regarding the publication of this paper.

\section{References}

[1] Ehrmann, A. (2019) On the Possible Use of Textile Fabrics for Vertical Farming. Tekstilec, 62, 34-41. https://doi.org/10.14502/Tekstilec2019.62.34-41

[2] Abu-Zeid, K. (2005) Egypt Water Development Report. United Nations Economic Commission for Africa Office for North Africa, ECA-NA/PUB/WATER/ EG/2.

[3] Abou Hussein, S.D. and Sawan, O.M. (2010) The Utilization of Agricultural Waste as One of the Environmental Issues in Egypt (A Case Study). Journal of Applied Sciences Research, 6, 1116-1124.

[4] Hamdy, A. (1993) Saline Irrigation Practices and Management. In: Lieth, H. and Al Masoom, A.A., Eds., Towards the Rational Use of High Salinity Tolerant Plants, Kluwer Academic Publisher, Amsterdam, 553-570.

[5] Hamdy, A. (1996) Use of Unconventional Water Resources as a Fresh Water Saving Practice. Proceedings of 16th Congress on Irrigation and Drainage, Cairo, 15-22 September 1996, 13-27.

[6] Abdel-Sattar, M.A. (2004) Using Compacted Rice Straw Bales for Growing Some Vegetables and Fruits. 2nd Edition, Menia Agriculture Technology Bulletin, Elmenia University, Egypt, 72 p.

[7] Abdel-Sattar, M.A, El-Marzoky, H.A. and Mohamed, A.I. (2008) Occurrence of Soil Borne Diseases in Strawberry Plants Grown on Compacted Rice Straw Bales Compared with Naturally Infested Soils. Journal of Plant Protection Research, 48, 223-235.

[8] Ali, E.M., Dessouki, S.S., Soliman, A.I. and El Shenawy, A.S. (2014) Characterization of Chemical Water Quality in the Nile River, Egypt. International Journal of Pure \& Applied Bioscience, 2, 35-53.

[9] Pinstrup-Anderson, P. (2018) Is It Time to Take Vertical Indoor Farming Seriously? Global Food Security, 17, 233-235. https://doi.org/10.1016/j.gfs.2017.09.002

[10] Mayer, H., Schuh, M. and Flachmann, C. (2018) Umweltokonomische Gesamtrechnungen. Flachenbelegung von Ernahrungsgutern 2008-2016. Statistisches Bundesamt (Destatis) No. 5385101-16900-4.

[11] Januszkiewicz, K. and Jarmusz, M. (2017) Envisioning Urban Farming for Food Security during the Climate Change Area. Vertical Farm within Highly Urbanized Areas. IOP Conference Series: Materials Science and Engineering, 245, Article ID: 
052094. https://doi.org/10.1088/1757-899X/245/5/052094

[12] Eaves, J. and Eaves. S. (2018) Comparing the Profitability of a Greenhouse to a Vertical Farm in Quebec. Canadian Journal of Agricultural Economics, 66, 43-54.

[13] Al-Kodmany, K. (2018) The Vertical Farm: A Review of Developments and Implications for the Vertical City. Buildings, 8, Article No. 24. https://doi.org/10.3390/buildings8020024

[14] Kerner, M. (2017) Anaerobic Domestic Waste Water Treatment Coupled to a Bioreactor Façade for the Production of Biogas, Heat and Biomass. Powerskin Conference: Proceedings, Munich, 19 January 2017, 38-47.

[15] Kerrison, P.D., Stanley, M., Hughes, S. and Adam, D. (2018) Textile Substrate Seeding of Saccharina latissimi Sporophytes Using a Binder: An Effective Method for the Aquaculture of Kelp. Algal Research, 33, 352-357. https://doi.org/10.1016/j.algal.2018.06.005

[16] Pellizzari, F.M., Absher, T., Yokoya N.S. and Oliveira, C.E. (2007) Cultivation of the Edible Green Seaweed Gayralia (Chlorophyta) in Southern Brazil. Journal of Applied Phycology, 19, Article No. 63. https://doi.org/10.1007/s10811-006-9111-1

[17] Sener, S. and Turemis, N.F. (2017) Effects of Various Mulch Materials on Fruit Quality Characteristics on Organically Grown Strawberries. Fresenius Environmental Bulletin, 26, 4616-4622.

[18] Rebarz, K., Borowczak, F., Gaj, R. and Frieske, T. (2015) Effects of Cover Type and Harvest Date on Yield, Quality and Cost-Effectiveness of Early Potato Cultivation. American Journal of Potato Research, 92, 359-366. https://doi.org/10.1007/s12230-015-9441-0

[19] ASTM D5867-12 (2020) Standard Test Methods for Measurement of Physical Properties of Raw Cotton by Cotton Classification Instruments. https://www.astm.org/d5867-12r20.html

[20] Egyptian General Authority for Standardization and Quality, Number (278/2013). https://www.eos.org.eg/ar/standard/2572. 